\title{
Investigating Fraud and Corruption: Characteristics of White-Collar Criminals
}

\author{
Petter Gottschalk* \\ BI Norwegian Business School, Europe
}

Submission: October 26, 2016; Published: November 22, 2016

*Corresponding author: Petter Gottschalk, BI Norwegian Business School, Nydalsveien-37, 0484 Oslo, Norway, Europe,

Email: petter.gottschalk@bi.no

\begin{abstract}
Social conflict theory suggests that the professional powerful and wealthy represent the elite and ruling class in society. The theory holds that laws and law enforcement are used by the dominant group to minimize threats to their interests. The justice system is biased and designed to protect the ruling class. Sanctioning of laws enables the dominant class to pressure a domestic order that allows its interests to be promoted and maintained. This article addresses the issue of deviant behavior by members of the ruling class. Specifically, it addresses the issue of law breaking by white-collar criminals. A number of reasons for law enforcement towards members of the elite are discussed in this article. In addition, a sample of convicted white-collar criminals in Norway is presented.
\end{abstract}

Keywords: Financial crime; White-collar crime; Policing; Conflict theory

\section{Introduction}

Criminal investigation is an applied science that involves the study of facts, used to identify, locate and prove the guilt or innocence of an individual suspected of white-collar crime. A complete criminal investigation can include searching, interviewing, collecting and preserving. Interviewing is one form of communication used extensively in investigations. Whether used to screen individuals, to elicit information from a witness to an incident, or to obtain a confession, a good interview can have a significant impact on the progress of an investigation. Criminal investigators are supposed to utilize innovative techniques and technological resources to find relevant facts as close as possible to the truth and present them in an objective way. The most economically disadvantaged members of society are not the only ones committing crime. Members of the privileged socioeconomic class are also engaged in criminal behavior. The types of crime may differ from those of the lower classes, such as business executives bribing public officials to achieve contracts, chief accountants manipulating balance sheets to avoid taxes, and procurement managers approving fake invoices for personal gain.

\section{Characteristics of White-Collar Criminals}

Criminal behavior by members of the privileged socioeconomic class is labeled white-collar crime. According to Brightman and Sutherland's [1-3] theory of white-collar crime from 1939 was controversial, particularly since many of the academics in the audience perceived themselves to be members of the upper echelon of American society. Despite his critics, Sutherland's theory of white-collar criminality served as the catalyst for an area of research that continues today. In particular, differential association theory proposes that a person associating with individuals who have deviant or unlawful mores, values, and norms learns criminal behavior. Certain characteristics play a key role in placing individuals in a position to behave illegally; including the proposition that criminal behavior is learned through interaction with other persons in the upper echelon, as well as the interaction that occurs in small intimate groups.

In contrast to Sutherland, Bright man [1] differs slightly regarding the definition of white-collar crime. While societal status may still determine access to wealth and property, he argues that the term white-collar crime should be broader in scope and include virtually any non-violent act committed for financial gain, regardless of one's social status. For example, access to technology, such as personal computers and the Internet, now allows individuals from all social classes to buy and sell stocks or engage in similar activities that were once the bastion of the financial elite. In Sutherland's definition of whitecollar crime, a white-collar criminal is a person of respectability and high social status who commits crime in the course of his 
occupation. This excludes many crimes of the upper class, such as most cases of murder, adultery, and intoxication, since these are not customarily a part of their job-related procedures [4]. It also excludes lower class criminals committing financial crime, as pointed out by Bright man [1].

What Sutherland meant by respectable and high social status individuals are not quite clear, but in today's business world we can assume he intended to refer to business managers and executives. They are, for the most part, individuals with power and influence that is associated with respectability and high social status. Part of the standard view of white-collar offenders is that they are mainstream, law-abiding individuals. They are assumed to be irregular offenders, rather than people who engage in crime on a regular basis [4]: Unlike the run-ofthe-mill common street criminal who usually has had repeated contacts with the criminal justice system, white-collar offenders are thought not to have prior criminal records.

When white-collar criminals appear before their sentencing judges, they can correctly claim to be first-time offenders. They are wealthy, highly educated, and socially connected. They are elite individuals, according to the description and attitudes of white-collar criminals as suggested by Sutherland. Therefore, very few white-collar criminals are put on trial, and even fewer upper class criminals are sentenced to imprisonment. This is in contrast to most financial crime sentences, where financial criminals appear in the justice system when typically not without being wealthy, highly educated, or socially connected. White-collar criminals are not entrenched in criminal lifestyles as common street criminals. White-collar crime can be defined in terms of the offense, the offender or both. If white-collar crime is defined in terms of the offense, it means crime against property for personal or organizational gain. It is a property crime committed by non-physical means and by concealment or deception [4]. If white-collar crime is defined in terms of the offender, it means crime committed by upper class members of society for personal or organizational gain. It is individuals who are wealthy, highly educated, and socially connected, and they are typically employed by, and in, legitimate organizations.

In summary, a white-collar criminal is typically a member of the privileged socioeconomic class in society, who behaves illegally in non-violent acts committed for financial gain. The criminal is a person of respectability, who commits crime in a professional setting, where criminal activities are concealed and disguised in organizational work by law-abiding behavior. The criminal has power and influence, and enjoys trust from others in privileged networks. White-collar crime incidents are offences committed by those in professional occupations conducting dishonest activities, by themselves or their agents, for financial gain. Finally, the white-collar criminal does not consider own actions as crime and has no guilt feeling. When the criminal is detected, often media coverage follows. The criminal has resources to hire a top white-collar attorney. White-collar criminals are sentenced differently and possibly milder than street criminals.

\section{Social conflict theory}

Social conflict theory suggests that the powerful and wealthy in the upper class of society define what is right and what is wrong. The rich and mighty people can behave like "robber barons" because they make the laws. Therefore, the ruling class does not consider a white-collar offence as a regular crime, and certainly not similar to street crime. Why would the powerful punish their own elite members? [5,6]. Social conflict theory views financial crime as a function of the conflict that exists in society [7-9]. The theory suggests that class conflict causes crime in any society, and that those in power create laws to protect their rights and interests. For example, embezzlement by employees is as a violation of law to protect the interests of the employer. However, it might be argued that an employer must and should protect own assets. Bank fraud is a crime to protect the powerful banking sector.

However, in the perspective of conflict theory one might argue that a bank should have systems making bank fraud impossible. If an employee has no opportunity to commit embezzlement, and if a fraudster has no opportunity to commit bank fraud, then these kinds of financial crime would not occur, and there would be no need to have laws against such offenses. Law enforcement protects powerful companies against counterfeit products, although they should be able to protect themselves by reducing opportunities for the production of counterfeit products. Social conflict theory holds that laws and law enforcement are used by dominant groups in society to minimize threats to their interests posed by those whom they perceive as dangerous and greedy [10]. Crime is defined by legal codes and sanctioned by institutions of criminal justice to secure order in society. The ruling class secures order in the ruled class by means of laws and law enforcement. Conflicts and clashes between interest groups are restrained and stabilized by law enforcement [5].

According to social conflict theory, the justice system is biased and designed to protect the wealthy and powerful. The wealthy and powerful can take substantial assets out of their own companies at their own discretion whenever they like, although employed workers in the companies were the ones who created the values. The superrich can exploit their own wealth that they created as owners of corporations as long as they do not hurt other share holders. Employees have no right to object. It is no crime to take out values from own enterprises and build private mansions for the money. This is no crime by the owners. Even when the owners just inherited the wealth created by earlier generations, they can dispose freely of it for private consumption $[6,11]$. Similarly, top executives who are on each other's corporate boards grant each other salaries that are ten or twenty times higher than regular employee salaries. As Haines [12] puts it, financial practices that threaten corporate interests, 
such as embezzlement, are clearly identified as criminal even as obscenely high salaries remain relatively untouched by regulatory controls". Furthermore, sharp practices such as insider trading that threaten confidence in equities markets have enjoyed vigorous prosecution, since the powerful see them as opaque transactions that give an unfair advantage to those who are not members of the market institutions.

Karl Marx who analyzed capitalism and suggested the transition to socialism and ultimately to communism, created the basis for social conflict theory. Capitalism is an economic system in which persons privately own trade, industries, firms, shops and means of production and operate these enterprises or profit. Socialism is an economic system characterized by cooperative enterprises, common ownership, and state ownership. Communism is a socioeconomic system structured upon the common ownership of the means of production and characterized by the absence of social classes. Marxist criminology views the competitive nature of the capitalist system as a major cause of financial crime $[9,10]$. It focuses on what creates stability and continuity in society, and it adopts a predefined political philosophy. Marxist criminology focuses on why things change by identifying the disruptive forces in capitalist societies, and describing how power, wealth, prestige, and perceptions of the world divide every society. The economic struggle is the central venue for the Marxists. Marx divided society into two unequal classes and demonstrated the inequality in the historical transition from patrician and slave to capitalist and wage worker.

It is the rulers versus the ruled. Marx also underlined that all societies have a certain hierarchy wherein the higher class has more privileges than the lower one. In a capitalist society where economic resources equate to power, it is in the interest of the ascendant class to maintain economic stratification in order to dictate the legal order [10]. When economic resources equate to power, then conflict and competition between groups will occur for scarce resources such as education, housing and jobs. Dominant groups can reduce the threat of other groups in the competition for resources through social control and criminal punishment [6]. In Marxist criminology, capitalism is a criminogenic society, i.e., a society that has a tendency to produce criminality. Capitalism is a system of economic production in which power is concentrated in the hands of a few, with the majority existing in a dependency relationship to the powerful [8]: This class-based economic order is maintained by a criminal justice apparatus that serves the interests of the wealthy at the expense of the poor. Those who challenge this system of production are destined for social control, especially if they are seen as a serious threat to the system.

Another German theorist was Max Weber, who wrote about classes in society, economic exploitation of people, political repression, and conflict within society. Neither Marx nor Weber wrote extensively about theories of crime or criminal behavior, but their theoretical perspective served as a good basis for conflict theory. Economic inequalities advance to assume disproportionate power in society and lead to social conflict [7]. Conflict theory provides an explanation of crime, since it is concerned with social inequality, class and racial differences, and the power used by the ruling class through its criminal justice apparatus. Conflict theorists see inequality based on differences in wealth, status, ideas, and religious beliefs. Not only do capitalist societies generate vast inequalities of wealth, but also those who own the wealth, who control large corporations and financial and commercial institutions, influence those who have political power to get the laws they want [8].

Conflict theory is a perspective in criminology that emphasize the social, political, or material inequality of a social group [11], that draw attention to power differentials, such as class conflict. Crime stems from conflict between different segments of society fueled by a system of domination based on inequality, alienation, and justice. Crime is harm that comes from differences in power [7]. Conflict is a fundamental social process. Society is largely shaped by the competing interests of social groups who struggle for dominance in order to enact or maintain a social structure most beneficial to them [11]: Conflict theory asserts that the relative power of a given social group dictates social order in that powerful groups not only control the lawmakers, but also the law enforcement apparatus of the state. In essence, laws are made which serve the interests of the privileged, and the police are used to suppress and control any segment of society that poses a threat to the status quo. Of course, there are a number of other crime causations, such as social, biological, environmental, economic, and physiological factors.

According to conflict theory, economic inequalities and repression lead to deviant behavior. Laws, law-breaking, and law enforcement are factors that evolve from and contribute to social conflicts and strengthen the dominant position of powerful individuals. Laws tend to penalize behavior of certain classes, and not individuals, due to the fact that it is the more powerful classes that are in a position to pronounce certain actions as illegal. The ruling class is faced with the decision which values to enforce when making laws. Criminal law plays the role of a social control mechanism. Certain types of conduct are prohibited, and certain kinds of sanctions are imposed for their infringement. The ruling class in society has the power to define certain behavior as deviant, while the ruled class might be of a differing opinion about what is right and what is wrong. Criminal laws are established mainly for the protection and development of the institutions of capitalism. Through laws, the powerful class exercises its power and controls the resources. An example is alcohol versus drug laws. Alcohol is legal, while drugs are illegal in most capitalist societies. Hagan [13] argues that the reason why the prohibition of narcotics outlasts the prohibition of alcohol is that historically the use of different drugs has been 
associated with minority groups, whereas alcohol has been a socially acceptable intoxicant used by members of the middle and upper classes.

Drug laws are specifically, if not explicitly, targeted at looser groups in society. As a result, alcohol prohibition was eventually repealed, while drug laws are still in force. In addition to laws and law breaking, sanctioning of laws in terms of law enforcement is a factor that evolves from and contributes to strengthen the dominant position of the ruling class. Even if some of the misconduct and offenses by members of the ruling class are determined by law as white-collar crime, law enforcement is often reluctant to investigate and prosecute the criminals. They may be too powerful with friends in key positions [14]. Furthermore, the size of the police force is typically larger for policing the lower classes. As an example, Norwegian police has two national units for investigations of violent crime and financial crime respectively. While the National Criminal Investigation Service has 700 employees, the National Authority for Investigation and Prosecution of Economic Crime and Environmental Crime has only 140 employees. Thus, combating financial crime has only 20 percent of the resources available to combating street crime. As stated by Chamlin [15], "crime control practices are disproportionately responsive to the concerns and fears of the more powerful segments of society."

Kane [16] studied the relationship between the size of the police force and minority population on the precinct level in New York City. The study shows that the police force increased when minority population fractions increased. The study supports the minority group-threat hypothesis that the percentage of black and Latino populations in US cities can predict variations in municipal police resources. Specifically, the study found that increases in the percentage of Latino populations of precincts can predict changes in police deployment, and the link between Latino populations and police deployment is nonlinear. This leads to police perception of the area as an offense space, and they tend to choose aggressive policing in the area. Sanctioning of laws enables the dominant economic class to pressure a domestic order that allows its interests to be promoted and maintained. Economic stratification is so important to the ruling class that they will pressure legislators to enact repressive measures intended to control groups considered volatile and threatening [10]. Conflict theory of crime control contends that the political state functions to further the distinctive interests of the most powerful segments of society. Within the context of crime control, this means suppressing illegal activities of out-group members that particularly endanger social elites or violate their behavioral norms [15].

Law enforcement targeted at white-collar criminals is nonaggressive and often discrete not only because of the upper class affiliation. Another reason is white-collar defendants' ability to recruit top defense lawyers who apply symbolic defense in addition to substance defense, as well as information control, in their work for white-collar clients [17]. It is well-known that having a well-qualified and possibly famous attorney increases one's chances of a favorable outcome in any legal dispute. According to Slyke and Bales [18], theory and empirical research often have agreed that white-collar offenders benefit from leniency at the sentencing stage of criminal justice system processing. Since white-collar crime is crime by the wealthy and powerful, it seems to contradict social conflict theory. There are no reasons why the wealthy and powerful would like to see laws that turn their own actions to regular criminal offences. When Sutherland [2-3] first coined the term "white-collar crime", there were indeed reactions in the audience of upper-class people. They asked why one should define actions by privileged individuals of the influential classes as crime at the level of street crime by ordinary criminals. According to Bright man [1], Sutherland's theory of white-collar crime first presented in 1939 was controversial, particularly since many of the academics in the audience perceived themselves to be members of the upper echelon in American society. The audience was the American Sociological Association where Sutherland gave his address and first presented his theory of white-collar crime.

\section{Reasons for prosecution}

Veblen's [19] sociological study of the "leisured classes" and their rapacious conspicuous consumption had an influence on Sutherland's [2-3] research. Josephson [20] who coined the term "robber barons" in the 1930ties was also an influential scholar at that time. Therefore, Sutherland's work on white-collar crime seems to fit with conflict theory, where he might have seen a need to reduce the level of conflict in society by defining obvious unjustified misconduct by privileged individuals as regular crime. This is in line with Arrigo and Bernard [21], who applies conflict theory to explain initiatives for more prosecution of white-collar criminals. Seron and Munger [11] quoted that "The plain fact is that in a new stage of capitalism, class divides as ruthlessly as it did in the age of the Robber Barons." Another reason for starting to define capitalists and other persons of respectability and high social status as regular criminals when they abuse their powers for personal or organizational profit is the need of governments to gain some kind of control over the business sector and the market economy. Business and professional elites had achieved political influence beyond what most democratic governments found acceptable. Even worse, some enterprises were so powerful that they became almost untouchable for government interventions. They were "too powerful to fail, (and) too powerful to jail" [14].

A third reason for the prosecution of the wealthy and powerful is that their own laws did not intend to target members of their own class. The lawmakers had others in society in mind. Caught by surprise that members of their own class violate their own laws leads the ruling class to turn laws against their own allies. When those allies demonstrate non-conforming and deviant behavior, others in the ruling class take on the task of 
prosecuting deviating members of the elite. "As we are reminded today, those who make the laws don't have the right to break the laws", Richard Frankel, the specialist agent in charge of the Criminal Division of the New York office of the Federal Bureau of Investigation, said at a news conference. FBI held its news conference as Sheldon Silver, the speaker of the State Assembly in New York, faced prosecuted for corruption.

State prosecutors charged Silver with having exploited his position as one of the most powerful politicians in the state of New York to obtain millions of dollars in bribes and kickbacks. Prosecutors accused Silver's law practice of being a fiction where the sources of large payments of bribes were hiding [22]. Silver was arrested on Manhattan on a five-count indictment in January 2015. US attorney Preet Bharara alleged that the Manhattan democrat used New York's ethics laws to hide his scheme - allowing him to become wealthy off his position in power [23]. He resigned a few weeks later as speaker [24]. At the same time, Malcolm A. Smith, a former majority leader of the New York State Senate, was convicted of federal corruption charges including bribery, wire fraud and extortion [25]. A fourth reason might be disappointment within the ruling class. The ruling class in society faces decisions over which values to enforce. When individuals in their own upper-level class violate some of these values, then the majority defines it as a crime. Those who violate values of fair competition among capitalists and market access, for example, are potential criminals, even if they belong to the same class as that condemning them. A fifth reason might be the victim of crime. If the victim of white-collar crime is another person in the upper class, then the ruling class would like to protect that person.

Victimization of upper-class members by other upper-class members can be considered a crime. Upper-class members need protection against deviant individuals in their own class. It is an inter-group conflict in the dominant class [6]. Maybe Madoff can serve as an example. Rich Jews placed their money in Madoff's investment fund with the promise and expectation that the rate of return would be extraordinary good. But instead they lost their money. Wealthy people were victims of Madoff's Ponzi scheme. Such behavior by Madoff had to be sanctioned, and Madoff received a record prison sentence of 150 years [26].

Above we phrased the question: Why should the powerful punish their own? Four answers have emerged:

i. reduce the level of conflict between rich and poor in society;

ii. increase government control over the business sector;

iii. avoid those making the laws breaking the laws;

iv. punish those who do not behave according to elite values, and

v. Punish those upper-class members that victimize other upper-class members.
Criminological attention on the activities of business enterprises and other organizations, their creativity and power, remains in a conflict with political influence of business executives, capitalists and members of the professional elites (issue ii above). Haines [12] discusses corporate fraud as an example, where she argues that: Criminalization of corporate fraud deflects attention to one of these actors, the business and its directors, without clear recognition of the role played by government itself. Haines [12] argues that governments critically, in close consultation with the professions, "enact legal and regulatory reforms that engender confidence in both the accuracy of accounts and materiality of money while also further institutionalizing their underlying ambiguities".

Hence, even as governments are excited to sanction corporate criminals with more vigor, they are at the same time implicated in the creation of corporate criminals. Corporate fraud implies that there has been a criminal misrepresentation of a financial or business state of affairs by one or more individuals for financial gain, where banks, shareholders and tax authorities are among the victims. Yet, misrepresentation is a matter of opinion rather than accuracy. For example, estimating values of products in stock is no exact science. If nobody wants to buy products in stock, they have no value. While governments work at arm's length through external auditors, law enforcement is reluctant to prosecute unless misrepresentation of the value of a business is completely out of range.

\section{Characteristics of white-collar crime}

White-collar crime is a broad concept that covers all illegal behavior that takes advantage of positions of professional authority and power as well as opportunity structures available within business for personal and corporate gain [27]: Crimes such as embezzlement, fraud and insider trading, on the one hand, and market manipulation, profit exaggeration, and product misrepresentation on the other, add up to a massive criminal domain. Criminal opportunities are now recognized as an important cause of all crime. Without opportunity, there can be no a crime. Opportunities are important causes of white-collar crime, where the opportunity structures may be different from those of other kinds of crime. These differences create special difficulties for control, but they also provide new openings for control [4].

Collins and Schmidt [28] apply a definition provided by the US Department of Justice: Nonviolent crime for financial gain committed by means of deception by persons whose occupational status is entrepreneurial, professional or semiprofessional and utilizing their special occupational skills and opportunities; also, nonviolent crime for financial gain utilizing deception and committed by anyone having special technical and professional knowledge of business and government, irrespective the person's occupation. Blickle et al. [29] apply the same definition that: White-collar crime is non-violent crime for 
financial gain committed by means of deception. The term whitecollar refers to the characteristics of the occupational position, such as power in the executive position. Therefore, white-collar crime refers to upper-level occupational crime [28].

\section{Sample of white-collar criminals}

To identify a substantial sample of white-collar criminals and to collect relevant information about each criminal, there are several options available. However, in a small country like Norway with a population of only five million people, available sample size is limited. One available option would be to study court cases involving white-collar criminals. A challenge here would be to identify relevant laws and sentences that correspond with our definition of not only white-collar crime, but also required characteristics of white-collar criminals. Another available option is to study newspaper articles, where the journalists have already conducted some form of selection of upper class, white-collar individuals convicted in court of financial crime. Another advantage of this approach is that the cases are publicly known, which makes it more acceptable to identify cases by individual white-collar names. Therefore, the latter option was chosen for this research [17]. As suggested in the research literature, most white-collar criminals are men. This is confirmed in our sample of 369 persons, which includes only 25 female criminals and 344 male criminals. Less than seven percent women can be explained by lack of opportunity [4] and other gender-related factors.

Most famous anecdotal cases such as Madoff, Rajaratman and Schilling are men in their fifties or older. This is confirmed in our sample where the average age is 48 years old when convicted in court. These average numbers are similar to a study by Blickle et al. [29] of 76 convicted German white-collar criminals. In their responding sample, there were 6 female criminals and 70 male criminals. The mean age of the offenders in Germany was 47 years. Similarly, the sample applied by Langton and Piquero [30] consisted of $84 \%$ men and $16 \%$ women in white-collar crime. In their sample, there was a mean age of 40 years. A study in the Netherlands of 644 prosecuted white-collar criminals between 2008 and 2012 shows that the average age was 42 years. There were $85 \%$ men and 15 percent women. The most common financial crime category was tax fraud [31]. The youngest whitecollar criminal in Norway was 17 years and the oldest was 77 years old when convicted. A distinction is made between age upon conviction and age at the time of committing the crime. On average, a person was convicted 5 years after the crime, thus the average age when committing white-collar crime in Norway and getting caught for it is 43 years old.

All persons in the sample received a jail sentence for whitecollar crime. The longest jail sentence is 9 years and the shortest is 26 days, and the mean average is 2.3 years imprisonment. Compared to famous US cases mentioned above, these sentences are quite modest. However, in a Norwegian context these jail sentences are quite substantial and only surpassed by organized crime and murder. Also, when comparing to the sample used by Blickle et al. [29] of white-collar criminals in Germany, the difference is less pronounced, as the average was 3.9 years imprisonment in Germany in their sample of 76 convicts. The average jail sentence in Norway is 2.3 years, and 3.9 years in Germany [29]. In comparison, white-collar offenders in the United States have faced sentences that far exceed those imposed in previous years. For example, Bernard Ebbers, former CEO of WorldCom, was sentenced to twenty-five years; Jeffrey Skilling, former CEO of Enron, was sentenced to twenty-four years and four months; and Adelphia founder John Rigas received a sentence of fifteen years, along with his son Timothy Rigas, the CFO of the company, who received a twenty-year sentence. Podgor [32] argues that these greatly increased sentences result in part from the application of the United States sentencing guidelines structure, which factors in the amount of fraud loss suffered in the computation of time.

\section{Conclusion}

Although the sentencing guidelines have a degree of flexibility, resulting from the previously mentioned Supreme Court decision in United States v. Booker, the culture of mandated guidelines still permeates the structure and, as such, prominently influences the judiciary. Equally influential in such sentencing is the fact that as parole no longer exists in the federal system, the time given to these individuals is likely to closely correlate with the sentence that they will serve. Despite short jail sentences, white-collar crime cases are taken seriously by the court system as well as the prison service. Also in the public, no excuses are accepted for their crime. When released from prison, very few are able to regain their positions in society: in terms of prestige, network and financial freedom. When asked what they found the worst consequence to be, whether media attention, duration of imprisonment, family collapse or financial ruin, answers differ. Many offenders seem to apply techniques based on neutralization theory [33].

White-collar crime involves some form of social deviance and represents a breakdown in social order. According to Heath [34], white-collar criminals tend to apply techniques of neutralization. These techniques are used by offenders to deny the criminality of their actions. Examples of neutralization techniques are

a. Denial of responsibility;

b. Denial of injury;

c. Denial of the victim;

d. Condemnation of the condemners;

e. Appeal to higher loyalties;

f. Everyone else is doing it; and

g. Claim to entitlement. 
The offender may claim an entitlement to act as he did, either because he was subject to a moral obligation, or because of some misdeed perpetrated by the victim [17].

\section{References}

1. Hank J Brightman (2009) Today's White-Collar Crime: Legal, Investigative and Theoretical Perspectives. Routledge, Taylor and Francis Group, USA

2. Edwin H Sutherland (1940) White-Collar Criminality. American Sociological Review 5: 1-12.

3. EH Sutherland (1949) White Collar Crime. Holt Rinehart and Winston, USA.

4. Benson ML, Simpson SS (2009) White-Collar Crime: An Opportunity Perspective, Criminology and Justice Series. Routledge, USA.

5. Schwendinger Herman, Schwendinger Julia (2014) Defenders of Order or Guardians of Human Rights? Social Justice 40(1-2): 87-117.

6. Darren Wheelock, Olga Semukhina, Nicolai N Demidov (2011) Perceived group threat and punitive attitudes in Russia and the United States. British Journal of Criminology 51(6): 937-959.

7. Mark M Lanier, Stuart Henry (2009a) Conflict and Radical Theories. In: Essential Criminology. ( $3^{\text {rd }}$ edn), Chapter 3, West view, USA.

8. Mark M Lanier, Stuart Henry (2009b) Capitalism as a Criminogenic Society - Conflict, Marxist, and Radical Theories of Crime. In: Essential Criminology ( $3^{\text {rd }}$ edn), Chapter 10, West view, USA.

9. Larry J Siegel (2011) Criminology. (11 ${ }^{\text {th }}$ edn), Wadsworth Publishing, USA.

10. Matthew Petrocelli, Alex R Piquero, Michael R Smith (2003) Conflict theory and racial profiling: An empirical analysis of police traffic stop data. Journal of Criminal Justice 31(1): 1-11.

11. Carroll Seron, Frank Munger (1996) Law and inequality: Race, Gender and of Course, Class. Annual Review of Sociology 22: 187-212.

12. Fiona Haines (2014) Corporate fraud as misplaced confidence? Exploring ambiguity in the accuracy of accounts and the materiality of money. Theoretical Criminology 18(1): 20-37.

13. John Hagan (1980) The legislation of crime and delinquency: A review of theory, method, and research. Law and Society Review 14(3): 603628.

14. Henry N Pontell, William K Black, Gilbert Geis (2014) Too big to fail, too powerful to jail? On the absence of criminal prosecutions after the 2008 financial meltdown. Crime, Law and Social Change 61(1): 1-13.

15. Mitchell B Chamlin (2009) Threat to whom? Conflict, consensus, and social control. Deviant Behavior 30(6): 539-559.

16. Robert J Kane (2003) Social control in the metropolis: A communitylevel examination of the minority group-threat hypothesis. Justice Quarterly 20(2): 265-295.
17. Petter Gottschalk (2015) Financial Crime and White-Collar Criminals An Empirical and Theoretical Survey for Research. Palgrave Macmillan Press, USA.

18. Shanna R Van Slyke, William D Bales (2013) Gender dynamics in the sentencing of white-collar offenders. Criminal Justice Studies 26(2): 168-196.

19. Thorstein Veblen (1899) The Theory of the Leisure Class: An Economic Study of Institutions. Macmillan, USA.

20. Matthew Josephson (1962) The Robber Barons: The Classic Account of the Influential Capitalists who Transformed America's Future. Harcourt, USA.

21. Bruce A Arrigo, Thomas J Bernard (1997) Postmodern criminology in relation to radical and conflict criminology. Critical Criminology 8(2): 39-60.

22. William k Rashbaum, Thomas Kaplan (2015) US says assembly speaker took millions in payoffs, abusing office. The New York Times.

23. Spector J (2015) Lawmaker accused in graft scheme. USA Today, USA.

24. McKinley J (2015) Settlement in Suit against Ex-Lawmaker. The New York Times, USA.

25. Vega T (2015) Ex-State Senate Chief Is Guilty of Bribery. The New York Times, USA.

26. Srinivasan C Ragothaman (2014) The Madoff Debacle: What are the Lessons? Issues in Accounting Education 29(1): 271-285.

27. Michael Kempa (2010) Combating white-collar crime in Canada: serving victim needs and market integrity. Journal of Financial Crime 17(2): 251-264.

28. Judith M Collins, Frank L Schmidt (1993) Personality, Integrity and White Collar Crime: A Construct Validity Study. Personnel Psychology 46(2): 295-311.

29. Gerhard Blickle, Alexander Schlegel, Pantaleon Fassbender, Uwe Klein (2006) Some Personality Correlates of Business White-Collar Crime. Applied Psychology: An International Review 55(2): 220-233.

30. Lynn Langton, Nicole Leeper Piquero (2007) Can general strain theory explain white-collar crime? A preliminary investigation of the relationship between strain and select white-collar offenses. Journal of Criminal Justice 35(1): 1-15.

31. Joost HR van Onna, Victor R van der Geest, Wim Huisman, Adriaan JM Denkers (2014) Criminal Trajectories of White-Collar Offenders. Crime \& Delinquency 51(6): 759-784.

32. Ellen S Podgor (2007) The challenge of white collar sentencing. Journal of Criminal Law and Criminology 97(3): 1-10.

33. Mikko Siponen, Anthony Vance (2010) Neutralization: New Insights into the Problem of Employee Information Security Policy Violations. MIS Quarterly 34(3): 487-502.

34. Joseph Heath (2008) Business Ethics and Moral Motivation: A Criminological Perspective. Journal of Business Ethics 83: 595-614.

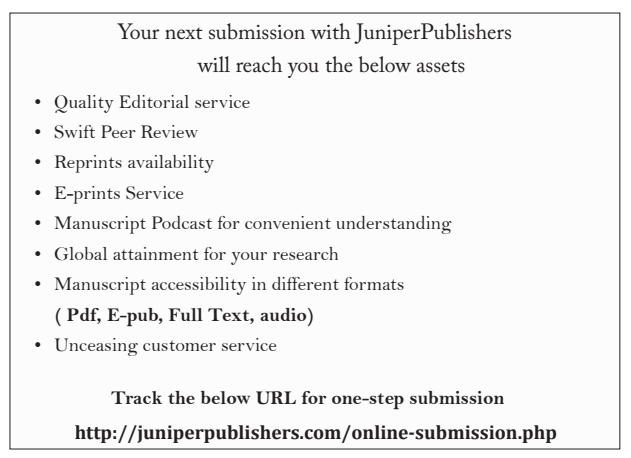

